\title{
HUBUNGAN ANTARA PERILAKU KEWARGAAN ORGANISASIONAL DAN KINERJA TUGAS
}

\author{
D. Wahyu Ariani (dwriani@gmail.com) \\ Fakultas Ekonomi, Universitas Atma Jaya Yogyakarta
}

\begin{abstract}
The main purpose of this study is to find out relationship between organizational citizenship behavior and task performance in banking industries in Indonesia. Organizational citizenship behavior is composed of four components: altruism, civic virtue, and sportmanship. To analyzed results mean, standard devistion, and correlation analysis techniques are used. 636 questionnaires were received and response rate 95 percent. Results prove that organizational citizenship behaviors do not have positive relationship with task performance.
\end{abstract}

Keywords: Civic Virtue, Altruism, Sportmanship, Organizational Citizenship Behavior, Task Performance

\section{PENDAHULUAN}

Menurut Allen dan Rush (2001), perilaku kewargaan organisasional merupakan konsep moderen dalam perilaku organisasional. Perilaku kewargaan organisasional juga penting dalam mencapai keberhasilan organisasi karena antesedennya memungkinkan karyawan dapat bekerja dengan baik. Perilaku kewargaan organisasional dalam perusahaan dapat membantu meningkatkan kinerja tugas atau konerja organisasional. Katz mengidentifikasi tiga perilaku karyawan yang penting bagi keefektifan organisasi, yaitu masuk dan tinggal dalam organisasi sebagai karyawan; melakukan peran khusus yang diperlukan; dan terikat dalam kegiatan inovatif dan spontan atau tidak terencana yang berada di luar peran yang dilakukan (Konovsky \& Pugh, 1994). Perilaku yang ketiga inilah yang disebut dengan Perilaku Kewargaan Organisasional yang merupakan perilaku yang tidak secara langsung atau tidak secara eksplisit berada dalam sistem formal dan dalam pemberian penghargaan organisasi. Perilaku tersebut dipandang penting karena tidak ditentukan standarnya, namun berpengaruh dalam menilai kinerja dan keefektifan organisasi (Allen \& Rush, 1998; MacKenzie et al., 1993; Podsakoff et al.,1997; Podsakoff \& MacKenzie, 1994; Podsakoff \& MacKenzie, 1997).

Katz dan Kahn (1966) menyatakan bahwa, perilaku kewargaan organisasional merupakan model kegiatan yang membuat organisasi secara intrinsik dapat bekerjasama dan berhubungan dalam konteks sistem terbuka. Agar organisasi efektif, individu harus masuk ke dalam sistem tersebut, mau menunjukkan peran dengan kriteria minimal untuk mencapai kinerjanya, dan melaksanakan perilaku yang inovatif dan spontan untuk menjalankan fungsi organisasi. Menurut Katz dan Kahn, pemberian penghargaan bagi individu hanya mampu mendorong kinerja yang sesuai dengan perannya, tetapi tidak dapat menciptakan motivasi untuk melaksanakan perilaku di luar perannya.

Dari pemahaman menurut beberapa orang ahli tersebut dapat dikatakan bahwa perilaku kewargaan organisasional muncul dari dalam individu berupa keinginannya memberikan kontribusi bagi organisasi. Hal ini disebabkan pada dasarnya karyawan memiliki komitmen untuk memberikan yang terbaik bagi organisasi. Keinginan tersebut mendorong individu untuk berperilaku secara spontan dalam suatu model kegiatan dan harus didukung oleh sistem yang ada, yaitu sistem yang kooperatif, informal, ada kolaborasi, didukung oleh pemimpinnya, dan ada pertukaran sosial maupun ekonomi.

Ada sejumlah ukuran keefektifan organisasi yang banyak disebut sebagai konsekuensi perilaku kewargaan organisasional, antara lain meningkatnya tingkat pendapatan, kepuasan pelanggan, kualitas pelayanan, dan profitabilitas (Bolino, 1999). Namun demikian, 
sejumlah peneliti masih memandang sisi lain konsekuensi perilaku kewargaan organisasional sebagai penghambat kemajuan karir individu (Bergeron, 2005) dan meningkatkan tingkat stres dan konflik kerja-keluarga (Bolino \& Turnley, 2003). Selain itu, untuk pekerjaan yang kaku dan harus selalu mengikuti prosedur kerja untuk keselamatan kerja, maka perilaku kewargaan organisasional tidak tepat untuk diterapkan (Hunt, 2002). Satu kontribusi dalam penelitian perilaku kewargaan organisasional adalah konsekuensi perilaku tersebut seringkali tidak diperhatikan manakala terdapat penyimpangan perilaku kewargaan organisasional seperti manajemen impresi (Schnake, 1991), politik (Tepper et al., 2004), dan mencari muka (ingratiation) (Eastman, 1994).

Terlepas dari semua konsekuensi positif ataupun negatif ini, perilaku kewargaan organisasional tetap mampu memberikan kontribusi bagi tercapainya keefektifan dan kinerja organisasi. Apabila perilaku kewargaan organisasional dapat meningkatkan keefektifan organisasi, maka pemimpin atau manajer akan menggunakan perilaku tersebut untuk mengevaluasi kinerja karyawan dan menjadikannya dasar pemberian penghargaan karyawan, serta berpengaruh pada karir karyawan. Di sinilah posisi perilaku kewargaan organisasional merupakan variabel independen dan merupakan syarat tercapainya kinerja organisasi. Adakalanya, unit yang dihasilkan dalam kinerja menurut perannya (in-role performance) dipandang sebagai konsekuensi perilaku tersebut (Mackenzie et al., 1993; Podsakoff et al., 1997; Podsakoff \& Mackenzie, 1994). Perilaku kewargaan organisasional selalu dipandang sebagai perilaku yang bersifat positif, sehingga konsekuensinya tidak menjadi kajian utama dalam pembahasannya.

Tujuan utama penelitian ini adalah menguji hubungan antara perilaku kewargaan organisasional dengan dimensi altruism, courtesy, civic virtue, sportmanship, dan kinerja tugas atau kinerja organisasional. Penelitian ini dapat memberikan kontribusi pada perkembangan konsep perilaku kewargaan organisasional terutama bila perilaku tersebut diterapkan di sektor jasa atau layanan dan hubungannya dengan kinerja tugas atau kinerja organisasional.

\section{LANDASAN TEORI DAN PERUMUSAN HIPOTESIS}

\section{Perilaku Kewargaan Organisasional}

Dennis W. Organ mengembangkan istilah perilaku kewargaan organisasional yang telah diungkapkan oleh Bateman dan Organ (1983) dan Smith et al.(1983). Pemahaman mereka didasarkan pada konsep Chester I. Barnard dengan istilah keinginan untuk bekerjasama dan konsep Katz yang membedakan antara kinerja yang tergantung perannya dan perilaku yang spontan dan inovatif (Podsakoff et al., 2000). Definisi menurut Organ yang dikutip oleh Podsakoff et al. (2000), perilaku kewargaan organisasional merupakan

"individual behavior that is discretionary, not directly or expicitly recognized by the formal reward system, and that in the aggregate promotes the effective functioning of the organization. By discretionary, we mean that the behavior is not an enforceable requirement of the role or the job description, that is the clearly specifiable terms of the person's employment contract with the organization, the behavior is rather a matter of personal choice, such that its omission is not generally understood as punishable."

Perilaku kewargaan meliputi dimensi fungsi individu dan kelompok yang nampak berada dalam pemikiran ketika mereka bekerjasama. Kerjasama ini melebihi peningkatan produktivitas yang terkait dengan fungsi organisasi formal seperti struktur kewenangan, peran, dan teknologi. Kerjasama juga meliputi sikap prososial individu yang bekerja dengan membutuhkan orang lain, seperti rekan kerja, supervisor, rekan dari departemen lain, sementara produktivitas atau efisiensi ditentukan oleh struktur formal atau struktur ekonomi 
organisasi (Smith et al., 1983). Perilaku yang dimaksud misalnya membantu rekan kerja tanpa mengharapkan imbalan, mengarahkan rekan kerja yang baru, bersikap sopan, memberikan saran bagi perkembangan dan kemajuan organisasi, dan sebagainya.

Perilaku kewargaan organisasional memang dipandang sebagai hal yang berbeda-beda menurut pandangan para peneliti. Untuk itulah diperlukan pengkajian terhadap pemahaman perilaku tersebut menurut para pencetusnya. Konsep perilaku kewargaan organisasional bukan merupakan hal yang baru. Chester I. Barnard menyatakan bahwa perilaku kewargaan organisasional merupakan keinginan individu untuk berkontribusi dalam sistem yang kooperatif. Sistem tersebut akan mendorong usaha yang kooperatif. Hal ini berarti perilaku tersebut merupakan komitmen individu yang timbul sebagai ekspresi kepuasannya. Roethlisberger dan Dickson menyatakan bahwa, perilaku kewargaan organisasional adalah suatu kolaborasi dan berada dalam sistem informal. Mereka juga menyatakan bahwa perilaku tersebut sudah ada sejak dilakukannya Hawthorne studies yang menunjukkan bahwa produktivitas bukan hanya karena faktor penerangan yang baik di tempat kerja, tetapi justru karena adanya hubungan yang baik dan informal di tempat kerja.

Sementara itu, Blau menyatakan perlunya pertukaran baik ekonomi maupun sosial sehingga individu mau melaksanakan perilaku kewargaan organisasional. Hal ini disebabkan interaksi di tempat kerja tidak mungkin bersifat ekonomi secara murni atau sosial secara murni, melainkan gabungan antara keduanya. Sedangkan Katz dan Kahn menyatakan bahwa, perilaku kewargaan organisasional merupakan model kegiatan yang membuat organisasi secara intrinsik dapat bekerjasama dan berhubungan dalam konteks sistem terbuka. Agar organisasi efektif, individu harus masuk ke dalam sistem tersebut, mau menunjukkan peran dengan kriteria minimal untuk mencapai kinerjanya, dan melaksanakan perilaku yang inovatif dan spontan untuk menjalankan fungsi organisasi. Menurut Katz dan Kahn, pemberian penghargaan bagi individu hanya mampu mendorong kinerja yang sesuai dengan perannya, tetapi tidak dapat menciptakan motivasi untuk melaksanakan perilaku di luar perannya.

Oliver Williamson menyatakan bahwa, perilaku kewargaan organisasional dapat timbul karena kontrak jangka panjang. la mengatakan bahwa, kontribusi karyawan meliputi pekerjaan yang terdefinisi dan bertanggung jawab terhadap tugasnya, kontribusi lain yang tidak terbatas namun mempengaruhi penilaian pimpinan, dan kontribusi yang secara spontan dilakukan tanpa perintah. Sementara itu, William Ouchi menyatakan bahwa, tidak penting bagi organisasi mengukur kinerja untuk mengendalikan atau mengarahkan karyawannya karena ada kecenderungan karyawan akan mengerjakan yang terbaik bagi organisasi. Teori pertukaran pemimpin-pengikut (leader-member exchange theory) juga mendorong perilaku kewargaan organisasional, bahkan korelasinya lebih besar daripada korelasi perilaku tersebut dengan kinerja yang sesuai dengan perannya. Hubungan pemimpin-pengikut ini terjadi secara informal dan dipengaruhi oleh kepercayaan.

Dari pemahaman menurut beberapa orang ahli tersebut dapat dikatakan bahwa perilaku kewargaan organisasional muncul dari dalam individu berupa keinginannya memberikan kontribusi bagi organisasi. Hal ini disebabkan pada dasarnya karyawan memiliki komitmen untuk memberikan yang terbaik bagi organisasi. Keinginan tersebut mendorong individu untuk berperilaku secara spontan dalam suatu model kegiatan dan harus didukung oleh sistem yang ada, yaitu sistem yang kooperatif, informal, ada kolaborasi, didukung oleh pemimpinnya, dan ada pertukaran sosial maupun ekonomi.

Selama lebih dari dua puluh tahun perkembangannya, banyak isu dan perdebatan dalam perilaku kewargaan organisasional, baik konseptual maupun metodologis. Isu dan perdebatan tersebut meliputi pemisahan (atau penyatuan) perilaku menurut peran (in-role behavior) dan perilaku di luar peran, dimensi-dimensi dalam perilaku tersebut, hingga anteseden dan konsekuensinya yang bersifat afektif dan kognitif, serta isu metodologis 
seperti perbedaan hasil penilaian perilaku kewargaan organisasional karyawan dengan beberapa sumber penilaian, tingkat pengukuran (level of measurement) dan tingkat analisis (level of analysis), hingga penelitian pada satu titik waktu (cross-section) dan berkelanjutan (longitudinal) dalam perilaku tersebut.

Literatur yang ada mengenai perilaku kewargaan organisasional, juga lebih memfokuskan pada hubungan antara perilaku tersebut dengan konstruk lain daripada pendefinisian dan pemahaman karakteristik perilaku itu sendiri. Istilah perilaku kewargaan organisasional ini bermacam-macam. Perilaku tersebut diberi istilah yang berbeda-beda oleh peneliti perilaku tersebut, yaitu organizational citizenship behavior (Organ \& Ryan, 1995; Organ \& Konovsky, 1989; Smith et al.,1983; Morrison, 1994; Van Dyne et al., 1994), prosocial behavior (George, 1991;), organizational spontaneity (George \& Brief, 1992; Katz \& Kahn, 1978; George \& Jones, 1997), extra-role behavior (VanDyne \& LePine,1998), contextual performance (Motowidlo \& Van Scooter, 1994; Borman \& Motowidlo, 1997; Van Scooter \& Motowidlo, 1996). Kelemahan dari banyaknya istilah tersebut adalah perbedaan antaristilah yang walaupun kecil namun sulit dipahami. Sedangkan keterkaitan perilaku tersebut dengan berbagai bidang atau disiplin ilmu lain juga akan mempersulit pengembangan literatur.

Perilaku kewargaan organisasional mempunyai beberapa dimensi. Studi empiris yang telah banyak dilakukan pada umumnya menggunakan lima dimensi, yaitu altruisme (altruism), kehati-hatian (conscientiousness) atau kepatuhan pada peraturan (generalized compliance), bersikap sportif (sportmanship), kesopanan (courtesy), dan kebaikan sebagai warga organisasi (civic virtue). Dimensi altruisme atau perilaku menolong (helping behavior) dan kehati-hatian seringkali dibedakan dalam dua dimensi. Hal ini disebabkan altruisme atau perilaku menolong dipahami sebagai keterlibatan secara sukarela membantu orang lain yang terkait dengan pekerjaannya, sedangkan kesopanan cenderung pada kerelaan untuk mencegah terjadinya masalah dalam organisasi. Dimensi kehati-hatian seringkali digantikan oleh kepatuhan pada peraturan organisasi. Hal ini disebabkan kepatuhan pada peraturan organisasi lebih bersifat impersonal daripada kehati-hatian dan tidak menyediakan bantuan khusus bagi seseorang, melainkan secara tidak langsung bagi seluruh organisasi (Podsakoff et al., 2000). Williams dan Anderson (1991) membagi dimensi perilaku kewargaan organisasional ke dalam dua kategori besar yaitu perilaku kewargaan organisasional pada level organisasi (OCBO) yang merupakan perilaku yang bermanfaat bagi organisasi secara umum seperti kepatuhan pada peraturan dan perilaku kewargaan organisasional pada level individu (OCBI) yang merupakan perilaku yang bermanfaat secara langsung bagi individu dan secara tidak langsung bagi organisasi, misalnya altruisme.

\section{Perilaku Sesuai Peran yang Dimainkan}

Kinerja adalah kemampuan kerja atau sesuatu yang yang dicapai atau prestasi yang diperlihatkan. Kinerja merupakan realitas obyektif yang dapat diketahui dan dapat diobservasi (Judge \& Ferris, 1993). Penilaian kinerja (performance appraisal) merupakan refleksi realita tersebut yang dapat dipercaya dan yang beralasan. Menurut Snell dan Youndt (1995), praktek-praktek manajemen (seleksi, pelatihan, penilaian kinerja, dan sistem pemberian penghargaan) masing-masing berpengaruh terhadap kinerja perusahaan, namun tidak dapat beroperasi secara independen satu dengan yang lain.

Penilaian kinerja mempunyai berbagai tujuan yang berbeda-beda antara lain, (1) pengembangan karyawan; (2) pendokumentasian kinerja karyawan; (3) memungkinkan karyawan mengekspresikan pandangannya; (4) menentukan upah atau penghargaan dan pemberian sangsi atau hukuman; dan (5) menentukan promosi karyawan (Milliman et al., 1995). Penilaian kinerja memang seringkali digunakan dalam organisasi sebagai dasar pengambilan keputusan adminstrasi bagi karyawan, seperti promosi dan mutasi atau transfer karyawan, alokasi penghargaan finansial, pengembangan karyawan termasuk identifikasi kebutuhan pelatihan dan mengetahui umpan balik kinerja, dan untuk penelitian individual. Oleh karena itu, yang terpenting dalam mengadakan penilaian kinerja adalah 
tujuan dilakukan penilaian kinerja tersebut harus jelas. Hal ini berpengaruh pada penyusunan instrumen, sistem dan prosedur penilaian, dan sampai sejauh mana penilaian dilakukan.

Caderblom (1982) menyatakan adanya tiga jenis penilaian kinerja, yaitu penilaian pengembangan, penilaian pemeliharaan, dan penilain perbaikan. Penilaian pengembangan (developmental appraisal) yang digunakan untuk mengembangkan karyawan yang mempunyai potensi dalam pekerjaan yang berbeda. Penilaian pemeliharaan (maintenance appraisal), yaitu penilaian kinerja karyawan yang berada dalam kondisi yang tetap dan tidak memungkinkan untuk diperbaiki dengan keterbatasan kemampuan, motivasi, atau ciri pekerjaannya. Penilaian ini difokuskan untuk mempertahankan kinerja pada tingkat tertentu. Penilaian perbaikan (remedial appraisal) digunakan untuk penilaian karyawan yang memiliki kinerja rendah atau karyawan yang memiliki keterbatasan namun mau mencoba meningkatkan kinerja mereka hingga level tertentu.

Menurut Decotiis dan Petit (1978), penilaian kinerja untuk tujuan administratif cenderung kurang akurat bila dibandingkan dengan penilaian kinerja untuk tujuan pengembangan karyawan atau sekedar penelitian individual. Ada beberapa teori yang menjadi dasar dalam penilaian kinerja karyawan. Teori peran (role theory) menyatakan bahwa kinerja karyawan merupakan fungsi dari individu dan organisasi atau mengombinasikan perspektif psikologi dan perspektif sosiologi (Katz \& Kahn, 1966). Kedua penulis tersebut juga menyatakan bahwa teori peran ini menghindarkan dari kesalahan pengukuran karena peran yang dimainkan karyawan didasarkan pada deskripsi pekerjaan sesuai dengan yang diharapkan organisasi dan disyaratkan dalam pencapaian kinerja (Welbourne et al., 1998).

Di sisi lain, teori identitas (identity theory) menunjukkan bahwa peran yang harus dimainkan karyawan menunjukkan identitasnya sebagai warga organisasi (Greenberg \& Baron, 2008). Organisasi mempengaruhi peran yang berhubungan dengan pekerjaan dalam berbagai cara, termasuk penghargaan terhadap perilaku, menuntut perilaku tertentu, mengenal perilaku karyawan baik secara formal maupun informal, dan menghukum karyawan bila perilakunya menyimpang. Dengan mengombinasikan teori peran dan teori identitas, karyawan akan mendapat penilaian kinerja yang baik bila mampu melakukan peran dalam tugas dan peran di luar tugasnya atau perannya sebagai warga organisasi.

Ilgen dan Favero (1985) menyatakan ada beberapa teori yang dapat mendasari penilaian kinerja, yaitu teori atribusi (attribution theory), teori kepribadian implisit (implicit personality theory), dan teori kognitif sosial (social cognitive theory). Teori atribusi menyatakan bahwa interaksi yang nyata antara penilai dan yang dinilai pekerjaannya akan membantu keakurasian penilaian kinerja tersebut. Teori kepribadian implisit menyatakan bahwa dalam penilaian kinerja bisa terjadi adanya distorsi sitematik (systematic distortion) dan dan efek halo (halo effect). Distorsi Sistematik didasarkan pada hubungan antara penilai yang didasarkan pada ingatannya (memory based) dan tidak adanya hubungan antara penilai dan perilaku yang dinilai. Sementara efek halo merupakan keterkaitan antara sifat yang dijustifikasi dari perilaku yang nampak. Kedua jenis bias ini mengganggu dalam penilaian kinerja. Hal ini dapat diatasi dengan metode penilaian kinerja yang melibatkan banyak pihak yang benar-benar mengenali orang yang dinilai. Teori kognitif sosial (social cognitive theory) menyatakan bahwa penilaian kinerja sebaiknya menggunakan berbagai observasi dari waktu ke waktu dan mengadakan analisis terhadap informasi yang diperoleh dari berbagai sumber (Bandura, 2001). Selanjutnya, ada satu teori yang dikemukakan Taft tentang penilaian antar pribadi (interpersonal judgement) yang menyatakan bahwa keakuratan penilaian oleh satu orang terhadap orang lain ditentukan oleh (1) motivasi penilai untuk mengevaluasi secara akurat; (2) adanya norma atau standar untuk menilai secara tepat; dan (3) kemampuan penilai untuk mengevaluasi (Decotiis \& Petit, 1978).

Menurut Welbourne et al. (1998) banyak sistem pengukuran kinerja mengabaikan perilaku kerja yang berada di luar pekerjaan tersebut. Hal ini disebabkan penyusunan sistem 
penilaian kinerja cenderung memerlukan analisis pekerjaan formal. Analisis pekerjaan hanya dilakukan pada pekerjaan yang sesuai dengan yang direncanakan dan mengabaikan perilaku yang tidak berhubungan dengan pekerjaan. Penilaian kinerja sebaiknya didasarkan pada model kompetensi yang berfokus pada keahlian yang dibutuhkan oleh karyawan baik di masa kini maupun masa mendatang. Kinerja karyawan yang dinilai juga harus meliputi kinerja tugas (task performance) dan kinerja di luar tugas (non task performance atau contextual performance) (Motowidlo et al., 1997; Motowidlo \& Van Scooter, 1994).

Kinerja atau perilaku di luar tugas merupakan aspek unik dari kegiatan individu di tempat kerja, namun kegiatan ini berada di luar persyaratan formal dalam pekerjaan mereka, bersifat bebas dan tidak secara eksplisit berada dalam prosedur kerja dan sistem pemberian upah formal. Karena sifatnya yang bebas tersebut, perilaku di luar peran ini akan menurun bila dilakukan pengawasan (Niehoff \& Moorman, 1993). Pemberian penghargaan kepada mereka yang disebut warga yang baik sulit dilakukan karena belum ada standar yang baku. Namun demikian, keterikatan individu pada kegiatan yang dilakukan secara sukarela ini dikenal penting bagi kinerja dan keefektifan organisasi (Borman \& Motowidlo, 1997; Motowidlo \& Van Scotter, 1994; Motowidlo et al., 1997).

Berdasarkan penelitian yang telah dilakukan mengenai perbedaan perilaku menurut perannya dan perilaku di luar perannya, beberapa peneliti menyatakan bahwa kedua tipe perilaku tersebut adalah dua hal yang berbeda (Van Dyne \& LePine, 1998; LePine \& Van Dyne, 2001; Williams \& Anderson, 1991; Organ, 1997; LePine et al., 2002). Peneliti lain menyatakan bahwa perbedaan pendefinisian perilaku kewargaan organisasional sebagai perilaku yang sesuai dengan peran dan yang berada di luar peran sulit dilakukan karena faktor pendefinisian peran dan tanggungjawab (Morrison, 1994); faktor posisi sebagai supervisor atau karyawan (Lam et al., 1999); faktor pengawasan supervisor (Zellar et al., 2002); dan faktor perbedaan gender (lihat misalnya penelitian Kidder,1993; Love et al., 2001; Vey \& Campbell, 2004; Kidder \& Parks, 2001). Oleh karena itu, hipotesis dalam penelitian ini adalah tidak ada hubugan antara dimensi altruisme, kesopanan, penerimaan sebagai warga organisasi dan perilaku sebagai warga dengan perilaku yang sesuai peran yang harus dimainkan sebagai warga organisasi.

\section{METODE PENELITIAN}

Penelitian ini dilakukan dengan metode survei. Metode pengumpulan data yang digunakan dalam penelitian ini adalah metode survei berdasar pada kriteria yang disarankan oleh Sekaran (2003), yaitu tujuan penelitian, keakuratan metode survei, tersedianya sumber data dan fasilitas penelitian, waktu yang diperlukan untuk penelitian, dan biaya yang dikeluarkan. Selain itu, penelitian survei dikembangkan dalam pendekatan positivis dengan memberikan pertanyaan pada responden mengenai keyakinan, pendapat, karakteristik, dan perilaku di masa lalu atau masa kini (Neuman, 2006). Penelitian survei digunakan untuk menguji hubungan antara variabel-variabel dan mampu memprediksi level atau variabel dengan mengetahui variabel lain (Saks, Schmitt, \& Klimoks, 2000).

Penelitian survei seringkali digunakan untuk melakukan survei sikap dan mempelajari hubungan antara sikap kerja seperti kepuasan kerja dan perilaku karyawan. Metode survei memberikan hasil yang akurat, ilmiah, cepat, efisien, dan meliputi sampel dalam jumlah besar (Zikmund, 1991). Data yang diperoleh dengan metode survei juga dapat diandalkan (Saks et al., 2000). Penelitian ini menggunakan metode survei dengan kuesioner yang dilakukan sendiri. Dibandingkan dengan empat metode survei lainnya (wawancara tatap muka, kuesioner melalui surat, kuesioner melalui telepon, kuesioner melalui media elektronik, atau kombinasi metode-metode survei tersebut), metode survei yang dilakukan sendiri merupakan metode yang terbaik (Cooper \& Schindler, 2001; Neuman, 2006; Sekaran, 2003). Keunggulan metode ini antara lain dalam hal tingkat respon, kerjasama responden, kerahasiaan responden, mendapatkan jawaban atas pertanyaan sensitif, banyaknya data 
yang dapat dikumpulkan, fleksibilitas dalam pengumpulan data, penggunaan stimulus fisik, adanya kontrol terhadap sampel, dan mampu meminimalkan item pertanyaan yang tidak terjawab. Walaupun demikian, ada beberapa kelemahan atau kesalahan yang ditemui peneliti dalam survei, yaitu kesalahan non respon, akibat bias, dan kesalahan administratif. Namun peneliti telah berusaha meminimalkannya. Kesalahan non respon, direduksi dengan pemberitahuan awal kepada responden, memotivasi responden, membuat kuesioner yang baik dan menarik, memberikan insentif berupa hadiah atau cinderamata kepada responden, dan mengecek kelengkapan kuesioner saat menerima kuesioner.

Setelah menentukan lokasi penelitian, peneliti mengirimkan surat ijin ke kantor-kantor cabang bank umum di kota tersebut. Selanjutnya dilakukan pemilihan karyawan atau staf teller yang memenuhi kriteria karyawan tetap (bukan kontrak, honorer, maupun paruh waktu) dan masa kerja lebih dari satu tahun. Peneliti mendapatkan ijin dari 128 kantor cabang bank umum di 16 kota besar di Pulau Jawa. Metode pengambilan sampel yang digunakan dalam penelitian ini adalah nonprobability sampling. Dalam metode ini, elemenelemen dalam populasi tidak memiliki probabilitas yang sama untuk dipilih sebagai sampel dalam penelitian (Sekaran, 2003; Cooper \& Schindler, 2001). Teknik pengambilan sampel nonprobabilistik yang dipilih adalah purposive sampling. Metode ini dipilih karena kasir yang merupakan obyek penelitian akan mampu memberikan informasi yang diharapkan karena memenuhi kriteria yang sesuai dengan tujuan penelitian. Kriteria kasir yang dipilih sebagai sampel adalah kasir yang merupakan karyawan tetap bank umum tersebut dan telah bekerja minimal satu tahun. Penelitian ini menggunakan penilaian diri Penilaian diri sendiri biasanya dihadapkan pada permasalahan common method variance, consistency motif, ataupun leniency biases. Penilaian pimpinan atau supervisor juga menghadapi permasalahan seperti halo effect, memory distortion, ataupun selective memory.

\section{HASIL DAN PEMBAHASAN}

\section{Analisis Hasil Penelitian}

Penelitian ini menggunakan kuesioner yang dikembangkan oleh beberapa peneliti terdahulu yang dialihbahasakan (translation) dan dikembalikan ke dalam bahasa aslinya, (back trans/ation). Analisis faktor dilakukan untuk menguji validitas konstruk. Item pertanyaan yang digunakan diekstraksi menurut teori yang digunakan dalam penelitian ini. Kemudian, dengan rotasi varimax dan menggunakan factor loading minimal 0,5 sesuai dengan yang disarankan Hair, Black, Babin, Anderson, dan Tatham (2006) dicapai hasil pengujian validitas konstruk yang signifikan secara praktek (practically significant). Selanjutnya, item-item pernyataan yang telah memenuhi validitas konstruk dengan analisis faktor tersebut diuji reliabilitasnya. Tabel 1 merangkum banyaknya kuesioner yang valid dan hasil pengujian reliabilitas (internal consistency) dengan a.

Tabel 1.

Factor Loading dan Internal Consistency

\begin{tabular}{|l|r|r|r|r|r|}
\hline Item pertanyaan & Altruisme & Kesopanan & Kepatuhan & Kewargaan & Kinerja Tugas \\
\hline ALT1 & 0,686 & & & & \\
ALT2 & 0,593 & & & & \\
ALT3 & 0,534 & & & & \\
ALT4 & 0,673 & & & \\
ALT5 & 0,586 & & & \\
ALT6 & 0,579 & & & \\
ALT7 & 0,539 & & & \\
CRT8 & & 0,558 & & \\
CRT9 & & 0,660 & & \\
CRT10 & & 0,747 & & & \\
CRT12 & & 0,696 & & & \\
CRT13 & & 0,757 & & & \\
\hline
\end{tabular}




\begin{tabular}{|c|c|c|c|c|c|}
\hline $\begin{array}{l}\text { SPR18 } \\
\text { SPR19 } \\
\text { SPR20 } \\
\text { SPR21 } \\
\text { SPR22 } \\
\text { SPR23 } \\
\text { SPR24 } \\
\text { CVV33 } \\
\text { CVV34 } \\
\text { CVV35 } \\
\text { CVV36 } \\
\text { IRB1 } \\
\text { IRB2 } \\
\text { IRB3 } \\
\text { IRB4 }\end{array}$ & & & $\begin{array}{l}0,571 \\
0,681 \\
0,725 \\
0,597 \\
0,589 \\
0,544 \\
0,685\end{array}$ & $\begin{array}{l}0,701 \\
0,671 \\
0,701 \\
0,785\end{array}$ & $\begin{array}{c} \\
\\
\\
\\
\\
\\
0,864 \\
0,846 \\
0,811 \\
0,805\end{array}$ \\
\hline Cronb.Alpha: & 0,7480 & 0,7668 & 0,7580 & 0,6847 & 0,8728 \\
\hline Mean & 3,6079 & 4,6877 & 4,4759 & 3,6377 & 3,9684 \\
\hline Std. Dev. & 0,56824 & 0,38480 & 0,45104 & 0,67195 & 0,41613 \\
\hline
\end{tabular}

Sumber : data primer diolah

Tabel 1 juga memaparkan pengujian reliabilitas dengan menggunakan internal consistency atau dengan Cronbach alpha (a ). Reliabilitas item pertanyaan ditunjukkan dengan nilai Cronbach alpha lebih besar atau sama dengan 0,7. Tabel 1 tersebut menunjukkan bahwa rerata masing-masing variebel cukup tinggi, yaitu berkisar antara 3,6079 hingga 4,6877 dan penyimpangan standar antara 0,38480 hingga 0,67195 . Setelah semua item pertanyaan dinyatakan valid dan reliabel, maka penelitin melakukan pengujian korelasi antar variabel agar dapat diuji sejak awal model penelitian yang digunakan. Hasil pengujian korelasi antarvariabel penelitian tersebut dipaparkan pada Tabel 2.

Tabel 2.

Korelasi Antarvariabel Penelitian

\begin{tabular}{|c|c|c|c|c|c|}
\hline & Altruism & Courtesy & Sportmanship & Civic Virtue & In-Role Behavior \\
\hline $\begin{array}{l}\text { Altruism } \\
\text { Pearson Correlation } \\
\text { Sign (2-tailed) } \\
N\end{array}$ & 636 & $\begin{array}{r}0,266^{* *} \\
0,000 \\
636\end{array}$ & $\begin{array}{r}0,171^{* *} \\
0,000 \\
636\end{array}$ & $\begin{array}{r}0,426^{* *} \\
0,000 \\
636\end{array}$ & $\begin{array}{r}0,052 \\
0,190 \\
636\end{array}$ \\
\hline $\begin{array}{l}\text { Courtesy } \\
\text { Pearson Correlation } \\
\text { Sign (2-tailed) } \\
N\end{array}$ & $\begin{array}{r}0,266^{* *} \\
0,000 \\
636 \\
\end{array}$ & $\begin{array}{r}1 \\
636 \\
\end{array}$ & $\begin{array}{r}0,368^{* *} \\
0,000 \\
636 \\
\end{array}$ & $\begin{array}{r}0,274^{* *} \\
0,000 \\
636 \\
\end{array}$ & $\begin{array}{r}0,046 \\
0,0251 \\
636 \\
\end{array}$ \\
\hline $\begin{array}{l}\text { Sportmanship } \\
\text { Pearson Correlation } \\
\text { Sign (2-tailed) } \\
N\end{array}$ & $\begin{array}{r}0,171^{* *} \\
0,000 \\
636 \\
\end{array}$ & $\begin{array}{r}0,368^{* *} \\
0,000 \\
636 \\
\end{array}$ & 636 & $\begin{array}{r}0,235^{* *} \\
0,000 \\
636 \\
\end{array}$ & $\begin{array}{r}0,076 \\
0,057 \\
636 \\
\end{array}$ \\
\hline $\begin{array}{l}\text { Civic Virtue } \\
\text { Pearson Correlation } \\
\text { Sign (2-tailed) } \\
\text { N }\end{array}$ & $\begin{array}{r}0,426^{* *} \\
0,000 \\
636\end{array}$ & $\begin{array}{r}0,274^{* *} \\
0,000 \\
636\end{array}$ & $\begin{array}{r}0,235^{* *} \\
0,000 \\
636\end{array}$ & $\begin{array}{r}1 \\
636\end{array}$ & $\begin{array}{r}0,058 \\
1,144 \\
636\end{array}$ \\
\hline $\begin{array}{l}\text { In-Role Behavior } \\
\text { Pearson Correlation } \\
\text { Sign (2-tailed) } \\
\mathrm{N}\end{array}$ & $\begin{array}{r}0,052 \\
0,190 \\
636 \\
\end{array}$ & $\begin{array}{r}0,046 \\
0,0251 \\
636 \\
\end{array}$ & $\begin{array}{r}0,076 \\
0,057 \\
636 \\
\end{array}$ & $\begin{array}{r}0,058 \\
1,144 \\
636 \\
\end{array}$ & $\begin{array}{r}1 \\
636 \\
\end{array}$ \\
\hline
\end{tabular}

* $p \leq 0,05{ }^{* *} p \leq 0,01$

Sumber : data primer diolah

Analisis korelasi pada Tabel 2 tersebut menunjukkan bahwa hubungan antar dimensi perilaku kewargaan organisasional adalah signifikan, yaitu berkisar antara 17,1\% hingga 42,6\%. 
Namun demikian, tidak korelasi yang signifikan antara berbagai dimensi perilaku kewargaan organisasional dan perilaku yang sesuai dengan peran yang harus dimainkan. Dengan kata lain hipotesis dalam penelitian ini didukung.

\section{Pembahasan Hasil Analisis}

Hasil penelitian ini menunjukkan adanya korelasi yang signifikan antar dimensi perilaku kewargaan organisasional. Hal ini menunjukkan sifat reflektif konstruk perilaku kewargaan organisasional untuk dimensi-dimensinya. Menurut MacKenzie, Podsakoff, dan Jarvis (2005), ciri konstruk yang bersifat reflektif antara lain (1) adanya korelasi antar dimensinya; (2) perubahan yang berupa pengurangan atau penambahan dimensi tidak mengubah arti konstruk tersebut, tetapi perubahan konstruk akan menyebabkan perubahan dimensi; (3) anteseden dan konsekuensi masing-masing dimensi dalam konstruk tersebut sama; dan (4) dimensi yang digunakan hanya merupakan refleksi dari konstruk yang diteliti. Selain itu, masing-masing dimensi menunjukkan adanya konsistensi secara internal yang menunjukkan adanya reliabilitas dalam konstruk tersebut (Jarvis, MacKenzie, \& Podsakoff, 2003).

Hasil penelitian ini juga menunjukkan korelasi yang rendah antar dimensi dalam perilaku kewargaan organisasional. Hal ini konsisten dengan hasil penelitian LePine et al. (2002), yang menyatakan bahwa antardimensi dalam perilaku kewargaan organisasional saling berkorelasi namun korelasinya rendah. Sementara itu, dalam dimensionalitas yang diusulkan oleh beberapa peneliti terdapat adanya saling tumpang tindih antarpeneliti walaupun mereka memberikan nama yang berbeda-beda.

Pemisahan atau penyatuan perilaku menurut peran dan perilaku di luar peran yang harus dilakukan anggota organisasi merupakan perdebatan yang masih membutuhkan pembuktian. Namun demikian, terlaksananya perilaku kewargaan organisasional dalam suatu organisasi menunjukkan kinerja individu yang melebihi standar berpengaruh dalam penilaian kinerja individu, pemberian penghargaan atau upah, dan dalam rekrutmen dan seleksi karyawan. Selain itu, terlaksananya perilaku kewargaan organisasional juga menunjukkan bahwa organisasi tersebut efektif dalam melaksanakan kegiatannya, sehingga aktivitas yang berada di luar standar pun dapat dilaksanakan dengan baik.

Perilaku kewargaan organisasional memberikan kontribusi bagi kinerja kelompok, unit, atau organisasi secara keseluruhan (Podsakoff \& MacKenzie, 1994; Podsakoff \& MacKenzie, 1997; Podsakoff et al., 1997). Menurut Podsakoff et al. (2000), perilaku kewargaan organisasional dapat meningkatkan keefektifan organisasi dengan cara mendorong produktivitas rekan kerja dan manajer, membebaskan pengunaan sumber daya sehingga karyawan dapat menggunakannya untuk tujuan yang lebih produktif, mengurangi kebutuhan akan penyediaan sumber daya yang sedikit untuk fungsi pemeliharaan, membantu mengkoordinir kegiatan di dalam maupun antarkelompok kerja, memperkuat kemampuan organisasi untuk menarik dan mempertahankan karyawan yang terbaik, meningkatkan stabilitas kinerja organisasi, dan memungkinkan organisasi beradaptasi secara lebih efektif terhadap perubahan lingkungan. Namun demikian, perilaku kewargaan organisasional tidak dapat diterapkan pada semua jenis pekerjaan (Hunt, 2002). Ada pekerjaan yang memandang perilaku kewargaan organisasional sebagai kegiatan atau tindakan yang membahayakan, yaitu pekerjaan yang harus mengikuti prosedur formal secara ketat. Bila ada kegiatan yang dilakukan tidak sesuai atau di luar prosedur formalnya, maka akan mengganggu keselamatan kerja.

Walaupun pengaruh perilaku kewargaan organisasional terhadap kinerja individu masih merupakan suatu perdebatan, namun hasil penelitian Mackenzie et al. (1993) menunjukkan bahwa perilaku tersebut mampu meningkatkan kinerja tenaga penjualan. Apabila perilaku kewargaan organisasional dapat meningkatkan keefektifan organisasi, maka pemimpin atau manajer akan menggunakan perilaku tersebut untuk mengevaluasi kinerja karyawan dan menjadikannya dasar pemberian penghargaan karyawan, serta berpengaruh pada 
karir karyawan. Di sinilah posisi perilaku kewargaan organisasional merupakan variabel independen dan merupakan syarat tercapainya kinerja organisasi. Adakalanya, unit yang dihasilkan dalam kinerja menurut perannya (in-role performance) dipandang sebagai konsekuensi perilaku tersebut (Mackenzie, et al., 1993; Podsakoff et al., 1997; Turnipseed \& Morkison, 2000; Podsakoff \& Mackenzie, 1994). Perilaku kewargaan organisasional selalu dipandang sebagai perilaku yang bersifat positif, sehingga konsekuensinya tidak menjadi kajian utama dalam pembahasannya.

Penelitian awal mengenai perilaku kewargaan organisasional mendefinsikan perilaku kewargaan organisasional sebagai terpisah dari kinerja sesuai peran dan menekankan bahwa perilaku tersebut dipandang sebagai di luar peran dan fungsi organisasi (Podsakoff et al., 2000). Kriteria tersebut membawa peneliti pada posisi yang kaku untuk membedakan antara perilaku yang sesuai dengan peran dan perilaku yang berada di luar peran yang harus dimainkan. Perbedaan tersebut akan bervariasi antara individu, kelompok, organisasi, pekerjaan, dan sebagainya dari waktu ke waktu.

Berdasarkan penelitian yang telah dilakukan mengenai perbedaan perilaku menurut perannya dan perilaku di luar perannya, beberapa peneliti menyatakan bahwa kedua tipe perilaku tersebut adalah dua hal yang berbeda. Peneliti lain menyatakan bahwa perbedaan pendefinisian perilaku kewargaan organisasional sebagai perilaku yang sesuai dengan peran dan yang berada di luar peran sulit dilakukan karena faktor pendefinisian peran dan tanggungjawab; faktor posisi sebagai supervisor atau karyawan; faktor pengawasan supervisor; dan faktor perbedaan gender.

Dalam organisasi kerja, perasaan memiliki (individu merasa terpenuhi kebutuhan dasarnya, merasa yakin terhadap kemampuannya mengerjakan tugas, dan identitas diri) merupakan kunci sikap yang berhubungan dengan pekerjaan (komitmen dan kepuasan), konsep diri dan perilaku (kinerja dan perilaku kewargaan organisasional) (Van Dyne \& Pierce, 2004). Perilaku individu meliputi perilaku yang sesuai dengan perannya dan perilaku yang berada di luar perannya atau yang disebut perilaku kewargaan organisasional. Hasil penelitian ini menunjukkan bahwa, konseptualisasi dan pengukuran perilaku kewargaan organisasional sulit dilakukan karena penentuan suatu perilaku yang sesuai peran dan yang di luar peran sangat dipengaruhi oleh pendefinisian perilaku tersebut oleh individu. Semakin luas individu mempersepsikan pekerjaan, semakin banyak proporsi perilaku atau pekerjaan yang sesuai dengan perannya. Keluasan pendefinisian pekerjaan persepsian juga berhubungan dengan kepuasan, komitmen afektif dan normatif, senioritas, masa kerja, dan status individu tersebut, sebagai pemimpin atau sebagai pengikut. Hal inilah yang merupakan salah satu penyebab perbedaan antara penilaian diri dan penilaian supervisor. Kesamaan jabatan atau pekerjaan dan seringnya berinteraksi antara karyawan dan supervisor akan membawa kesamaan dalam pendefinisian pekerjaannya.

Selain Morrison (1994), hasil penelitian Vey dan Campbell (2004) dan Lam et al. (1999) menunjukkan kesulitan pendefinisian perilaku kewargaan organisasional, apakah item-item dalam perilaku tersebut benar-benar mengukur perilaku kewargaan organisasional atau justru mengukur perilaku yang sesuai dengan peran yang harus dimainkan. Bahkan, dimensidimensi dalam perilaku kewargaan organisasional terutama dimensi organisasi (dimensi sportmanship dan civic virtue) dapat dikategorikan sebagai perilaku yang sesuai dengan perannya. Menurut Zellars et al., (2002), pemilihan setting penelitian sangat berperan dalam mendefinisikan perilaku kewargaan organisasional. Pada pekerjaan dengan supervisi ketat, karyawan akan mendefinisikan perilaku tersebut sebagai perilaku yang sesuai dengn peran yang harus dimainkan. Selain itu, status karyawan sebagai paruh waktu atau temporer, atau kontrak dengan struktur organisasi yang sangat birokratis akan merasa kurang terikat dalam perilaku kewargaan organisasional daripada karyawan penuh atau reguler atau permanen dengan struktur organisasi yang kurang birokratis (Stamper \& Van Dyne, 2001; Van Dyne \& Ang, 1998; Feather \& Rauter, 2004). 
Sementara itu, Williams dan Anderson (1991) secara tegas menunjukkan adanya perbedaan antara perilaku sesuai peran, perilaku kewargaan organisasional dimensi individu, dan perilaku kewargaan organisasional dimensi organisasi dan mengusulkan perlunya higher order factor models bagi ketiga dimensi tersebut. Salah satu cara untuk menguji perbedaan antara perilaku sesuai peran dan perilaku kewargaan organisasional adalah dengan menguji kontribusi kepribadian pada perilaku kewargaan organisasional dan pengalaman kerja pada perilaku yang sesuai peran (Bott et al., 2003). Hasilnya menunjukkan bahwa, kedua perilaku tersebut berbeda, karena perilaku yang sesuai peran dipengaruhi oleh pengalaman, sedang perilaku kewargaan organisasional dipengaruhi kepribadian. Namun, perbedaan antara perilaku kewargaan organisasional dimensi individu dan perilaku kewargaan organisasional dimensi organisasi belum diuji perbedaannya secara empiris.

\section{PENUTUP}

Penelitian ini menunjukkan bahwa dimensi altrisme, kesopanan, sikap sportif sebagai warga organisasi dan kebaikan sebagai warga organisasi saling berkorelasi signifikan, namun lemah. Hal ini menunjukkan sifat reflektif konstruk perilaku kewargaan organisasional. Keempat dimensi tersebut masing-masing tidak berkorelasi dengan perilaku yang sesuai dengan peran yang dimainkan. Beberapa penelitian sebelumnya masih selalu memperdebatkan hubungan antara perilaku di luar peran yang dimainkan dan perilaku yang sesuai peran yang dimainkan. Hal ini menunjukkan pendefinisian perilaku di luar peran yang dimainkan masih bersifat ambigu dan masih memerlukan dukungan penelitian empiris.

Penelitian ini memberikan kontribusi metodologis yang menunjukkan sifat reflektif perilaku di luar peran yang dimainkan. Kontribusi manajerial yang diperoleh dalam penelitian ini adalah perlunya kejelasan tugas dan tanggung jawab yang harus dilaksanakan karyawan dan perlunya pendefinisian penilaian kinerja karyawan. Apabila dalam suatu perusahaan tidak dikenal deskripsi pekerjaan yang jelas, maka penilaian kinerja hanyalah penilaian kinerja yang menilai perilaku di luar peran yang harus dimainkan.

\section{DAFTAR PUSTAKA}

Allen, T.D. dan Rush, M.C. (1998). The Effects of Organizational Citizenship Behavior on Performance Judgment : A Field Study and Laboratory Experiment. Journal of Applied Psychology, 83 (2) : 247-260

Bandura, A. (2001). Social Cognitive Theory: An Agentic Perspective. Ann. Rev. Psychol., 52 : $1-26$

Bateman, T.S. dan Organ, D.W. (1983). Job Satisfaction and The Good Soldier : The Relationship Between Affect and Employees'Citizenship. Academy of Management Journal, 26 (4) : 587- 595

Bergeron, C. (2005). Organizational Citizenship Behavior : A Negative Relationship to Career Outcome. Academy of Management Best Conference Paper.

Bolino, M.C. (1999). Citizenship and Impression Management : Good Soldiers or Good Actors ?. Academy of Management Review, 24 (1): 82-98

Bolino, M.C. dan Turnley, W.H. (2003). Going The Extra Mile : Cultivating and Managing Employee Citizenship Behavior. Academy of Management Executive, 17 (3) : 60-71

Borman, W.C. dan Motowidlo, S.J. (1997). Task Performance and Contextual Performance : The Meaning For Personnel Selection Research. Human Performance, 10 (2) : 99-109

Bott, J.P; Svyantek, D.J.; Goodman, S.A.; dan Bernal, D.S. (2003). Expanding The Performance Domain : Who Say Nice Guys Finish Last?. The International Journal of Organizational Analysis, 11 (2) : 137-152 
Caderblom, D. (1982). The Performance Appraisal Interview: A Review, Implications, and Suggestions. Academy of Management Journal, 7 (2): 219-227

Cooper, D.R dan Schindler, P.S. (2001). Business Research Methods. $7^{\text {th }}$ edition. Singapore : McGraw - Hill/ Irwin

Decotiis, T dan Petit, A. (1978). The Performance Appraissal Process: A Model and Some Testable Propositins. Academy of Management Review, 3 (3): 635-646

Eastman, K.K. (1994). In The Eyes of The Beholder: An Attributional Approach to Ingratiation and Organizational Citizenship Behavior. Academy of Management Journal, 37 (5) : 1379-1391

Feather, N.T. dan Rauter, K.A. (2004). Organizational Citizenship Behaviors in Relation to Job Status, Job Insecurity, Organizational Commitment and Identification, Job Satisfaction, and Work Values. Journal of Occupational and Organizational Psychology, $77: 81-94$

George, J.M. (1991). State or Trait : Effects of Positive Mood on Prosocial Behaviors at Work. Journal of Applied Psychology, 76 (2) : 299-307

George, J.M. dan Jones, G.R. (1997). Organizational Spontaneity in Context. Human Performance, $10(2): 153-170$

Greenberg, J. dan Baron, R.A. (2008). Behavior In Organizations : Understanding and Managing The Human Side of Work, $9^{\text {th }}$ edition. New Jersey : Prentice Hall

Hair, J.E.; Black, W.C. ; Babin, B.J. ; Anderson, R.E. ; dan Tatham, R.L. (2006). Multivariate Data Analysis. $6^{\text {th }}$ edition. New Jersey : Prentice-Hall International Inc.

Hunt, S.T. (2002). On The Virtues of Staying 'Inside of The Box' : Does Organizational Citizenship Behavior Detract from Performance in Taylorist Jobs? International Journal of Selection and Assessment, 10 (1/2): 152-159

llgen, D.R dan Favero, J.L. (1985). Limits in Generalization from Psychological Research to Performance Appraisal Processes. Academy of Management Review, 10 (2): 31 1-321

Jarvis, C.B.; MacKenzie, S.B.; dan Podsakoff, P.M. (2003). A Critical review of Construct Indicators and Measurement Model Misspecification in Marketing and Consumer Research. Journal of Consumer Research, 30 (2): 199-218

Judge, T.A. dan Ferris, G.R. (1993). Social Context of Performance Evaluation Decisions. Academy of Management Journal, 36 (1): 80-105

Katz, D. dan Kahn, R.L. (1966). The Social Psychology of Organization. New York : John Wiley and Sons, Inc.

Kidder, D.L. (1993). The Good Soldier: Who Is S(he) ?. Academy of Management Proceedings

Kidder, D.L. dan Parks, J.M. (2001). The Good Soldier : Who is s(he)?. Journal of Orgnizational Behavior, 22 : 939-959

Konovsky,M.A. dan Pugh, S.D. (1994). Citizenship Behavior and Social Exchange. Academy of Management Journal, 37 (3) : 656-669

Lam, S.S.K.; Hui, C. ; dan Law, K.S. (1999). Organizational Citizenship Behavior : Comparing Perspectives of Supervisors and Subordinates Across Four International Samples. Journal Of Applied Psychology, 84 (4) : 594-601

LePine, J.A. ; Erez, A. ; dan Johnson, D.E. (2002). The Nature and Dimensionality of Organizational Citizenship Behavior : A Critical Review and Meta-Analysis. Journal of Applied Psychology, 87 (1): 52-65

LePine, J.A. dan Van Dyne, L. (2001). Voice and Cooperative Behavior as Contrasting Forms of Contextual Performance : Evidence of Differential Relationships With Big Five 
Personality Characteristics and Cognitive Ability. Journal of Applied Psychology, 86 (2) : 326-336

Love, M.S. ; Macy, G. ; dan Dougherty, T.W. (2001). Batnard's Cooperative Systems and The Power of Coworker Effect. International Journal of Organizational Theory and Behavior, 4 (3\&4) :389-401

MacKenzie, S.B. ; Podsakoff, P.M. ; dan Fetter, R. (1993). The Impact of Organizational Citizenship Behavior on Evaluations of Salesperson Performance. Journal of Marketing, 57, January : 70-80

MacKenzie, S.B.; Podsakoff, P.M.; dan Jarvis, C.B. (2005). The problem of Measurement Model Misspecification in Behavioral and Organizational Research and Some Recommended Solution. Journal of Applied Psychology, 90 (4): 710-730

Milliman, J.F.; Nason, S.; Lowe, K.; Kim, N; dan Huo, P. (1995). An Empirical Study of Performance Appraisal Practices In Japan, Korea, Taiwan, and The U.S. Academy of Management Journal,

Morrison, E.W. (1994). Role Definition and Organizational Citizenship Behavior : The Importance of The Employee Perspective. Academy of Management Journal, 37 (6) :1543-1567

Motowidlo, S.J. ; Borman, W.C. ; dan Schmit, M.J. (1997). A Theory of Individual Differences in Task and Contextual Performance. Human Performance, 10 (2) : 71-83

Motowidlo, S.J. dan Van Scooter, J.R. (1994). Evidence That Task Performanxce Should be Distinguished From Contextual Performance. Journal of Applied Psychology, 79 (4) : 475-480

Neuman, W.L. (2006). Social Research Methods: Qualitative and Quantitative Approaches. $6^{\text {th }}$ edition. New York : Allyn and Bacon

Niehoff, B.P. dan Moorman, R.H. (1993). Justice as a Mediator of The Relationship Between Methods of Monitoring and Organizational Citizenship Behavior. Academy of Management Journal, 36 (3) : 527-556

Organ, D.W. (1997). Organizational Citizenship Behavior: It's Construct Clean-Up Time. Human Performance, 10 (2) : 85-97

Organ, D.W. dan Konovsky, M.A. (1989). Cognitive versus Affective Determinant of Organizational Citizenship Behavior. Journal of Applied Psychology, 74 (1) : 151-164

Organ, D.W. dan Ryan, K. (1995). A Meta-Analytic Review of Attitudinal and Dispositional Predictors of Organizational Citizenship Behavior. Personnel Psychology, 48 : 775-802

Podsakoff, P.M. ; Ahearne, M. ; dan MacKenzie, S.B. (1997). Organizational Citizenship Behavior and The Quantity and Quality of Work Group Performance. Journal of Applied Psychology, 82 (2) : 262-270

Podsakoff, P.M. dan MacKenzie, S.B. (1994). Organizational Citizenship Behavior. Journal of Marketing Research, XXXI, August : 351-363

Podsakoff, P.M. dan MacKenzie, S.B. (1997). Impact of Organizational Citizenship Behavior on Organizational Performance: A Review and Suggestions For Future Research. Human Performance, $10(2): 133-151$

Podsakoff, P.M.; MacKenzie, S.B.; Paine, J.B.; dan Bachrach, D.G. (2000). Organizational Citizenship Behavior : Critical Review of The Theoretical and Empirical Literature and Suggestions for Future Research. Journal of Management, 26 (3) : 513-563.

Sacks, A.M.; Schmitt, N.W.; dan Klomosk, R.J. (2000). Research, Measurement, and Evaluation of Human Resources. Canada: Nelson-Thomson Learning

Schnake, M. (1991). Organizational Citizenship : A Review, Proposal, Model, and Research Agenda. Human Relations, 44 : 735-759 
Sekaran, U. (2003). Research Methods For Business : Skill Building Approach. $4^{\text {nd }}$ edition. New York: John Wiey \& Sons, Inc.

Smith, C.A. ; Organ, D.W. ; dan Near, J.P. (1983). Organizational Citizenship Behavior : Its Nature and Antecedents. Journal of Applied Psychology, 68 (4) : 653-663

Snell, S.A. dan Youndt, M.A. (1995). Human Resource Management and Firm Performance : Testing a Vontingency Model of Executive Controls. Journal of Management, 21 (4), 711-737

Tepper, B.J. ; Hoobler, J. ; Duffy, M. K. ; dan Ensley, M.D. (2004). Moderators of The Relationship Between Coworkers' Organizational Citizenship Behavior and Fellow Employees' Attitudes. Journal of Applied Psychology, 89 (3) : 455-465

Tepper, B.J. ; Hoobler, J. ; Duffy, M. K. ; dan Ensley, M.D. (2004). Moderators of The Relationship Between Cowoprkers' Organizational Citizenship Behavior and Fellow Employees' Attitudes. Journal of Applied Psychology, 89 (3) : 455-465

Van Dyne, L. dan Ang, S. (1998). Organizational Citizenship Behavior of Contingent Workers in Singapore. Academy of Management Journal, 41 (6) : 692-703

Van Dyne, L. dan LePine, J.A. (1998). Helping and Voice Extra-Role Behaviors : Evidence of Construct and Predictive Validity. Academy of Management Journal, 41 (1) : 108-119

Van Dyne, L. dan Pierce, J.I. (2004). Psychological Ownership and Feelings of Possession : Three Field Studies Predicting Employee Attitudes and Organizational Citizenship Behavior. Journal of Organizational Behavior, 25 : 439-459

Van Scooter, J.R. dan Motowidlo, S.J. (1996). Interpersonal Facilitation and Job Dedication as Separate Facets of Contextual Performance. Journal of Applied Psychology, 81 (5) : 525-531

Vey, M.A. dan Campbell, J.P. (2004). In-Role or Extra-Role Organizatonal Citizenship Behavior : Which Are We Measuring?. Human Performance, 17 (1):119-135

Welborne, T.M.; Johnson, D.E.; dan Erez, A. (1998). The Role-Based Performance Scale: Validity Analysis of A Theory-Based Measure. Academy of Management Journal, 41 (5):540-555

Williams, L.J. dan Anderson, S.E. (1991). Job Satisfaction and Organizational Commitment as Predictors of Organizational Citizenship and In-Role Behaviors. Journal of Management, 17 (3) : 601-617

Zellarrs, K.L. ;Tepper, B.J. ; dan Duffy, M.K. (2002). Abusive Supervision and Subordinates' Organizational Citizenship Behavior. Journal of Applied Psychology, 87 (6) : 1068-1076

Zikmund, W.G. (1991). Exploring Marketing Research. Chicago, USA: Dryden Press. 